Article

\title{
The Stakeholder Salience Model Revisited: Evidence from Agri-Food Cooperatives in Spain
}

\author{
Cristina Pedrosa-Ortega *, $M^{\mathrm{a}}$ Jesús Hernández-Ortiz@, Elia García-Martí \\ and Manuel Carlos Vallejo-Martos
}

University of Jaén, Campus de Las Lagunillas, s/n, 23071 Jaén, Spain; mjhernan@ujaen.es (M.J.H.-O.); egarcia@ujaen.es (E.G.-M.); mvallejo@ujaen.es (M.C.V.-M.)

* Correspondence: cpedrosa@ujaen.es; Tel.: +34-953-213-670

Received: 15 November 2018; Accepted: 16 January 2019; Published: 22 January 2019

check for updates

\begin{abstract}
In recent decades, the importance of cooperatives in agri-food markets has been evident. Specifically, in Spain they represent a very important part of the agri-food industry. However, there is no significant evidence of substantial differences in their management, different from the general business case. The main objective of this study is to examine how a certain organizational context influences manager decisions and perceptions. The purpose is studying whether this influence causes changes to the main conclusions of the stakeholder salience original model. The working methodology consists of carrying out an exploratory and confirmatory factor analysis (from the data of 352 agri-food cooperatives in Spain) in order to test the psychometric properties of measurement scales, and the hypothesized relationships between attributes and stakeholder salience results are examined using structural equation modeling. Results show that the measurement of the stakeholder salience varies in agri-food cooperatives. The contributions of this study are to confirm that: (1) in agri-food cooperatives legitimacy is the first measurement of stakeholder salience, unlike the general business case where that is power; (2) the attribute of urgency remains unchanged from the proposed model; and (3) add to the original model the attribute of durability because of the permanence of the interest of stakeholders in agri-food cooperatives.
\end{abstract}

Keywords: agri-food cooperatives; stakeholder salience; sustainability; management

\section{Introduction}

Cooperation is an inevitable trend in the sustainable development of agricultural economy around the world. Cooperatives have gained prominent attention in recent years as strategic elements to achieve sustainable economic development and greater social cohesion [1]. The legal definition of a cooperative is "mutual aid economic organizations joined voluntarily and managed in a democratic manner by the producers and operators of the same kind of farm products, or by the providers or users of services for the same kind of agricultural production and operation" [2].

In recent decades, the importance of cooperative companies in agri-food markets has been evident. Within the European Union (EU), there are estimated to be 21,769 agri-food cooperatives with more than six million members and sales of approximately 347,000 million euros. These cooperatives process and commercialize over $40 \%$ of the agricultural production [3]. In Spain, there are approximately 3740 agri-food cooperatives with a turnover of 28,993 million euros and a total direct employment of 100,831 . The final agricultural production is 46,807 million euros, with net sales in the food industry of 96,419 million euros [4], which denotes the importance of this type of entity in the Spanish economy.

According to the International Cooperative Alliance (1995) there are seven principles that guide the cooperative movement: (1) free voluntary enrollment; (2) democratic management; (3) economic participation of members; (4) autonomy and independence; (5) education, training and information; 
(6) inter-cooperation; (7) interest in the community. These principles are the lifeblood of these businesses and the essence of their culture.

Cooperatives must take into account the various stakeholders surrounding the company: shareholders, employees, clients, government, and the community. In fact, one of the most interesting contexts in which stakeholder theory was applied was in cooperatives. It would seem to be an especially appropriate context for a test of stakeholder theory because cooperatives tend to be more balanced in their objectives between non-economic and economic enrichment of their members [5].

In relation to the stakeholder view of the firm, a company can last if it is able to build and maintain sustainable and durable relationships with all members of its stakeholder network. These relationships are essential assets that managers must manage, and they are the ultimate sources of organizational wealth [6]. In more detail, a sustainability-oriented company is fully aware of its responsibilities towards the different stakeholders and adopts methods and tools that allow it to improve its social, economic, and ecological performance [7]. However, certain issues arise from the stakeholder management: (a) Have all the groups been useful in the account in the same way and with the same weight in the company? (b) Is there a model that determines the relevance of each stakeholder? [8-10]; (c) And if so, are there differences about the stakeholder salience in agri-food cooperatives in comparison to other business? Our interest is in answering all these questions because there have been no previous works applied in cooperatives; this is where we see the originality and the value of this paper.

We examine whether the model of the stakeholder salience of agri-food cooperatives causes changes to the main conclusions of the original model to determine the stakeholder salience. Thus, some authors stated that the salience of stakeholders is given by the presence in each group of the attributes of power, urgency, and legitimacy [6]; other authors added a fourth attribute of durability to give dynamism to the original model [7].

For this purpose, the paper is structured in five sections after this introduction. The second section includes the theoretical foundation and hypotheses to be tested, and the third section establishes aspects of the methodology. The results are given in the fourth section and, finally, the discussion and conclusions are presented.

\section{Theoretical Foundation}

The sustainability of a firm depends on the sustainability of its stakeholder relationships: a company must consider and engage not only shareholders, employees, and clients, but also suppliers, public authorities, the local (or national, according to a firm's size) community, civil society in general, financial partners etc. Nowadays, and more and more in the future, the sustainability of stakeholder relationships must be the guiding principle for managerial decision-making and the pillar of a more comprehensive corporate strategy [7]. The theory of stakeholder identification and salience developed three important social science concepts to characterize stakeholders: power, legitimacy, and urgency [6]. These were labeled stakeholder attributes. They define stakeholder salience as "the degree to which managers give priority to competing stakeholder claims." The central relationship in their theory was that stakeholder salience increases with the number of stakeholder attributes.

They hypothesized and found support for a model of stakeholder salience in which managerial values and stakeholder attributes influence managerial perceptions of stakeholder salience [10]. Because stakeholder salience occurs in the minds of managers, these managers play a key role in the theory. In addition, some authors established that stakeholder salience is significantly affected by managerial cognitions and differentiation based on the unusual and novel in the immediate context [11,12]. These authors argue that such domination, differentiation, and novelty have an impact on managerial perceptions of the stakeholder attributes of power, legitimacy, and urgency; and so attempt to explain how attributes of stakeholders combine with managerial cognitions to create stakeholder salience in the minds of managers [13]. 
In fact, the nature of the perceptions of stakeholder salience, as well as the managerial responses to the claims of salient stakeholders, are likely to differ in important ways. Managers within such companies consider a set of moral principles when making decisions that may generate modifications to the original model. For these reasons, our interest is focused on agri-food cooperatives to discover if the manner of managing stakeholder relations corresponds to the model proposed by [8]. Below we describe the attributes that constitute the research model and establish hypotheses.

\subsection{Legitimacy}

Since the publication of [8], there has been some debate regarding whether legitimacy is a consequence of social construction [14], normative declaration [15], or some other option [13]. While our purpose is not to revisit this debate, we note that the core idea underlying stakeholder legitimacy that we utilize as a point of comparison in our argument has not changed vis-à-vis the original conception. We therefore continue to define legitimacy as a generalized perception or assumption that the actions of an entity are desirable, proper, or appropriate within some socially constructed system of norms, values, beliefs, and definitions [14]. However, as we will later argue, this socially constructed understanding differs markedly from the how legitimacy is understood within an agri-food cooperative.

Although much work has been done both theoretically and empirically on organizational legitimacy, the concept of stakeholder legitimacy has yet to be more widely explored [16,17]. Legitimacy is justified on ethical grounds, so if stakeholders have legitimate interest in an organization they must be considered as ends in themselves by the company.

Unlike the original stakeholder salience model, we consider that by following the proposals of [18] we are led to establish legitimacy as the first measurement of the perceived salience of stakeholders in agri-food cooperatives. The response to the legitimacy by companies (management) is derived from feelings toward others (morality) and moralist cultures have a genuine concern for the interests of stakeholders-with legitimacy as the primary driver of the salience perceived by managers (rather than power and urgency). This approach leads us to establish the first research hypothesis.

$H_{1}$ : In Spanish agri-food cooperatives, legitimacy has more influence than power and urgency in stakeholder salience.

\subsection{Power}

This attribute is the existence or the possibility of obtaining by a social actor the means or resources (technology, money, knowledge, logistics, and raw materials) and symbolic resources (prestige, reputation, and charisma) to impose his or her will on others $[19,20]$. This attribute is divided into utilitarian power, is based on material or financial resources; and normative social power, which is based on symbolic resources.

Specifically, utilitarian power may indicate that companies will generally pay more attention to and be more concerned about those stakeholders who control the basic resources needed for the survival of the company $[10,21]$. This dependence of companies on stakeholders for key resources results in power for the groups involved $[8,22]$ and influence over the company. Generally, the more dependent a company is, the more powerful the stakeholder [23,24]. Meanwhile, normative social power does not constitute a claim for material rewards. This power includes both normative symbols (prestige and esteem) and social symbols (love and acceptance).

As noted above, we suggest that [19]'s analysis of power in organizations provides additional fine-grained concepts that will enable us to distinguish stakeholder power in the general business setting from power in agri-food cooperatives. In the general model this attribute of power mostly explains the salience of each of the stakeholders in the company. Nevertheless, the internal logic and operation of agri-food cooperatives means that the weighting of attributes varies.

We agree that power and legitimacy help to define stakeholder salience. However, we argue that possessing urgency alone is not sufficient to grant stakeholder status to any claimant [17]. The urgency 
attribute provides a dynamic dimension to the salience framework, and although helpful and relevant in the prioritization of stakeholder claims, it is irrelevant when measuring the stakeholder salience. If the claimant does not have the power to affect the organization or a legitimate claim upon the organization, managers will not grant stakeholder status. The following hypothesis is proposed from this theoretical development.

$\mathrm{H}_{2}$ : In Spanish agri-food cooperatives, power has more influence than urgency in stakeholder salience.

\subsection{Urgency}

Urgency is the degree to which stakeholder claims call for immediate attention. Moreover, urgency has been defined in the general business context as a multidimensional construct that includes both: (a) time sensitivity, the degree to which managerial delay in attending to the claim or relationship is unacceptable to the stakeholder; and (b) criticality, the importance of the claim or the relationship to the stakeholder [8].

Some authors suggest that groups that only have the attribute of urgency cannot be considered stakeholders and so require the minimum of attention from managers [17]. If the claimant does not have the power to affect the organization or a legitimate claim upon the organization, then managers will not grant stakeholder status. Indeed, another authors found that no managers of the organizing committees of two large-scale sporting events considered that claimants possessing only urgency were salient [16].

Urgency is a booster of salience generated by either legitimacy or power, but is insufficient by itself. Managers identify and deal with stakeholders because they possess a legitimate claim upon the organization and/or the power to affect the organization. It is really a secondary attribute that merely provides the 'extra push' needed to make already salient issues more so. In either case, urgency acts as a booster of salience (low to moderate; moderate to high), determined by primary attributes (power and/or legitimacy), but generates no salience by itself [18]. With this theoretical approach, the following hypothesis is proposed.

$\mathrm{H}_{3}$ : There is no difference in the level of influence of urgency in stakeholder salience in Spanish agri-food cooperatives.

\subsection{Durability}

The attribute of durability adds a vision of the permanence of the stakeholder in the company and, therefore, the permanence of their interests in the company's actions [9]. A durable stakeholder will have a permanent interest in the actions of the company, while other stakeholders may have more time-limited expectations. Introducing a fourth stakeholder attribute, durability, adds a temporal component that complements stakeholder urgency analysis. Therefore, while stakeholder urgency is the ability to make immediate demands on the organization, durability is the likelihood of a stakeholder being able to continue making future demands on the organization.

Durability is defined as the attribute that represents the continuing ability of stakeholders to make legal, institutional, or other demands on the company. Power, legitimacy, and urgency are considered important attributes, but they do not adequately address long-term stakeholder management issues. This attribute helps management consider and motivate durable stakeholders alongside those who must be handled continuously over a long period of time [9].

Durability influences the perceived salience and we propose adding it to the general stakeholder model because agri-food cooperatives build codes in a way that reflects their economic and moral interests [25]. In companies with ongoing relationships in their environment based on moral codes, durable stakeholders can become very important for managers when making decisions because of the ongoing relationship and demands. It is insightful because it helps highlight the stakeholders that managers must continually confront, as well as considering other important stakeholder attributes.

$\mathrm{H}_{4}$ : In Spanish agri-food cooperatives, durability significantly influences stakeholder salience. 


\section{Methodology}

\subsection{Procedure}

Table 1 shows the operational aspects of the work, the process for obtaining the population, and the procedures used to obtain the primary information.

Table 1. Sample.

\begin{tabular}{ll}
\hline \multicolumn{2}{c}{ Agri-food Cooperatives } \\
\hline Population size & 3929 \\
Confidence level & $95 \% ; \mathrm{z}=1,96$ \\
Sample error & $5.0 \% ; p=\mathrm{q}=\frac{1}{2}$ \\
Interviewed subjects & Directors /managers \\
Population selection & SABI database \\
Methods for obtaining the information & Self-administered \\
Timeframe of the questionnaire & questionnaire \\
Sample & January-March 2016 \\
Information processing & 352 valid responses \\
\hline
\end{tabular}

As shown in Table 1, the final population was defined starting from the SABI (Analysis System of Iberian Balance Sheets) database and comprised a total of 3929 agri-food cooperatives. The primary data collection was made by telephone-administered questionnaire. The final sample was reached via telephone survey; we received a total of 352 valid questionnaires. Due to the fact that we are measuring the stakeholder salience, we considered that the interviewed subjects should be directors or managers, in order to collect information that was as accurate and reliable as possible.

The questionnaire was developed following the different stages: (1) preparation of an expert group; (2) preparation of the initial questionnaire; (3) preparation of items and scale dimensions; (4) pre-test the questionnaire; and (5) the final questionnaire (see Appendix A for a complete version of the questionnaire) [26].

\subsection{Measures}

Table 2 shows the variables used to measure stakeholder salience based on the collected attributes described above.

Table 2. Model variables, description, and references.

\begin{tabular}{|c|c|c|c|}
\hline FACTOR & DIMENSION & CODE & DESCRIPTION AND REFERENCES \\
\hline \multirow[t]{2}{*}{ POWER } & Utilitarian power & RESOURCE_USE & $\begin{array}{l}\text { Utilitarian power may indicate that companies will } \\
\text { generally pay more attention and be more concerned } \\
\text { about those stakeholders who control the basic } \\
\text { resources needed for the survival of } \\
\text { the company }[10,21] \text {. }\end{array}$ \\
\hline & $\begin{array}{l}\text { Social normative } \\
\text { power }\end{array}$ & IMAGE_ & $\begin{array}{l}\text { This power includes both normative symbols (prestige } \\
\text { and esteem) and social symbols (love and acceptance) } \\
\text { from the stakeholder to the company }[10,21] \text {. }\end{array}$ \\
\hline LEGITIMACY & & FAVOUR_ & $\begin{array}{l}\text { Is the generalized perception or assumption that the } \\
\text { actions of a stakeholder are desirable, proper, } \\
\text { or appropriate within some socially constructed } \\
\text { system of norms, values, beliefs, and definitions [14]. }\end{array}$ \\
\hline URGENCY & $\begin{array}{l}\text { CriticalityTime } \\
\text { sensitivity }\end{array}$ & INTERESTS_INSISTENCE_ & $\begin{array}{l}\text { (a) Criticality as to the importance of the claim or the } \\
\text { relationship to the stakeholder [8]. } \\
\text { (b) Time sensitivity is the degree to which managerial } \\
\text { delay in attending the claim or relationship is } \\
\text { unacceptable to the stakeholder [8]. }\end{array}$ \\
\hline DURABILITY & & INTERESTS_TIME_ & $\begin{array}{l}\text { Represents the continuing ability of stakeholders to } \\
\text { make legal, institutional, or other demands on } \\
\text { the company [9]. }\end{array}$ \\
\hline
\end{tabular}


Table 2. Cont

\begin{tabular}{clll}
\hline \multicolumn{1}{c}{ FACTOR } & \multicolumn{1}{c}{ DIMENSION } & CODE & \multicolumn{1}{c}{ DESCRIPTION AND REFERENCES } \\
\hline \multirow{2}{*}{$\begin{array}{l}\text { STAKEHOLDER } \\
\text { SALIENCE }\end{array}$} & \begin{tabular}{l} 
Importance \\
\cline { 2 - 3 }
\end{tabular} & IMPORTANCE_ & $\begin{array}{l}\text { a) It is the relevance that the manager perceives that } \\
\text { each stakeholder has [27]. }\end{array}$ \\
\cline { 2 - 4 } & Time of attention & ATTENTION_STAKEHOLDERS_ & $\begin{array}{l}\text { b) It refers to the time the manager spends to meet the } \\
\text { demands of each stakeholder [27]. }\end{array}$ \\
\hline
\end{tabular}

The model has three latent variables or second-order constructs (only measurable through other directly observable variables or indicators) and eight first-order constructs (directly observable from one indicator), as well as eight indicators. Once the constructs are developed and the indicators selected, we can see if the model provides a reasonable fit and so prove the convergent validity of these indicators [28].

To measure salience, we used the same stakeholders as the original model: shareholders (1); employees (2); clients (3); government (4); and the community (5). The method used to collect the necessary information to test the research hypotheses was the telephone administered questionnaire (see Appendix A for a complete version of the questionnaire).

\subsection{Statistical Procedures}

For the data used in this research, we conducted the following actions: a study of lost cases (missing data); detection and treatment of isolated observations (outliers) both univariate and multivariate; and testing of the assumptions required by the technique (first, univariate and multivariate normality to determine the method of analysis applicable; and second, verification of the existence of linear relationships between variables).

To study the dimensionality of the measurement scales, an exploratory factor analysis was made and the results are shown in Table 3.

Table 3. Dimensionality of the measurement scales.

\begin{tabular}{|c|c|c|c|c|c|}
\hline FACTOR & DIMENSION & VARIABLE & $\begin{array}{l}\text { WEIGHT } \\
\text { FACTOR }\end{array}$ & KMO/BARTLETT/LEVELSIG. & $\begin{array}{l}\text { EXPLAINED } \\
\text { VARIANCE }\end{array}$ \\
\hline \multirow{5}{*}{ LEGITIMACY } & & FAVOUR_1 & 0.794 & & \multirow{5}{*}{57.474} \\
\hline & & FAVOUR_2 & 0.690 & 0.842 & \\
\hline & & FAVOUR_3 & 0.741 & 680.039 & \\
\hline & & FAVOUR_4 & 0.724 & 0.000 & \\
\hline & & FAVOUR_5 & 0.737 & & \\
\hline \multirow{10}{*}{ POWER } & \multirow{5}{*}{$\begin{array}{l}\text { UTILIARIAN } \\
\text { POWER }\end{array}$} & RESOURCE_USE_1 & 0.891 & & \multirow{5}{*}{55.67} \\
\hline & & RESOURCE_USE_2 & 0.632 & 0.708 & \\
\hline & & RESOURCE_USE_3 & 0.729 & 625.673 & \\
\hline & & RESOURCE_USE_4 & 0.583 & 0.000 & \\
\hline & & RESOURCE_USE_5 & 0.697 & & \\
\hline & \multirow{5}{*}{$\begin{array}{l}\text { SOCIAL } \\
\text { NORMATIVE } \\
\text { POWER }\end{array}$} & IMAGE_1 & 0.727 & & \multirow{5}{*}{62.78} \\
\hline & & IMAGE_2 & 0.595 & 0.793 & \\
\hline & & IMAGE_3 & 0.679 & 923.115 & \\
\hline & & IMAGE_4 & 0.631 & 0.000 & \\
\hline & & IMAGE_5 & 0.579 & & \\
\hline \multirow{10}{*}{ URGENCY } & \multirow{5}{*}{ CRITICALITY } & INTERESTS_1 & 0.837 & & \multirow{5}{*}{61.34} \\
\hline & & INTERESTS_2 & 0.770 & 0.791 & \\
\hline & & INTERESTS_3 & 0.740 & 994.345 & \\
\hline & & INTERESTS_4 & 0.895 & 0.000 & \\
\hline & & INTERESTS_5 & 0.777 & & \\
\hline & \multirow{5}{*}{$\begin{array}{l}\text { TIME } \\
\text { SENSITIVITY }\end{array}$} & INSISTENCE_1 & 0.686 & & \multirow{5}{*}{58.54} \\
\hline & & INSISTENCE_2 & 0.736 & 0.797 & \\
\hline & & INSISTENCE_3 & 0.895 & 847.673 & \\
\hline & & INSISTENCE_4 & 0.812 & 0.000 & \\
\hline & & INSISTENCE_5 & 0.742 & & \\
\hline \multirow{5}{*}{ DURABILITY } & & INTERESTS_TIME_1 & 0.90 & & \multirow{5}{*}{69.85} \\
\hline & & INTERESTS_TIME_2 & 0.735 & 0.876 & \\
\hline & & INTERESTS_TIME_3 & 0.894 & 1576.001 & \\
\hline & & INTERESTS_TIME_4 & 0.861 & 0.000 & \\
\hline & & INTERESTS_TIME_5 & 0.776 & & \\
\hline
\end{tabular}


Table 3. Cont.

\begin{tabular}{|c|c|c|c|c|c|}
\hline FACTOR & DIMENSION & VARIABLE & $\begin{array}{l}\text { WEIGHT } \\
\text { FACTOR }\end{array}$ & KMO/BARTLETT/LEVELSIG. & $\begin{array}{l}\text { EXPLAINED } \\
\text { VARIANCE }\end{array}$ \\
\hline \multirow{11}{*}{$\begin{array}{l}\text { STAKEHOLDER } \\
\text { SALIENCE }\end{array}$} & \multirow{5}{*}{ IMPORTANCE } & IMPORTANCE_1 & 0.956 & & \multirow{5}{*}{55.82} \\
\hline & & IMPORTANCE_2 & 0.832 & 0.750 & \\
\hline & & IMPORTANCE_3 & 0.734 & 644.497 & \\
\hline & & IMPORTANCE_4 & 0.596 & 0.000 & \\
\hline & & IMPORTANCE_5 & 0.694 & \multirow{7}{*}{$\begin{array}{l}0.749 \\
611.475 \\
0.000\end{array}$} & \\
\hline & \multirow{6}{*}{$\begin{array}{l}\text { ATTENTION } \\
\text { TIME }\end{array}$} & ATTENTION_STAKEHOLDER & 0.580 & & \multirow{6}{*}{54.94} \\
\hline & & -1 & & & \\
\hline & & & 0.668 & & \\
\hline & & $\begin{array}{l}\text { ATTENTION_STAKEHOLDER } \\
\_3\end{array}$ & 0.788 & & \\
\hline & & $\begin{array}{l}\text { ATTENTION_STAKEHOLDER } \\
-4\end{array}$ & 0.746 & & \\
\hline & & $\begin{array}{l}\text { ATTENTION_STAKEHOLDER } \\
\_5\end{array}$ & 0.770 & & \\
\hline
\end{tabular}

It can be seen that the values of the KMO index justify the application of the exploratory factor analysis. It can also be seen that the factor loadings (the weight of each variable observed in the corresponding dimension) are above 0.5 in every case, which, together with the results of the Bartlett test of sphericity and the explained variance, highlight the appropriateness of the grouping of the variables around the corresponding dimension or construct.

For the reliability study, we used the Cronbach $\alpha$ co-efficient, with the reliability index composed of each construct (IFC or RHO). This indicated internal consistency in measuring the construct; values above 0.7 are recommendable [29].

In our study, we observed that both the Cronbach $\alpha$ and the composite reliability index are in line with recommendations, as shown in Table 4.

Table 4. Reliability of the measurement scales.

\begin{tabular}{cccc}
\hline \multicolumn{2}{c}{ FACTOR/DIMENSION } & $\alpha$ Cronbach & IFC \\
\hline \multirow{2}{*}{ LOWERITIMACY } & 0.731 & 0.740 \\
\multirow{2}{*}{ URGENCY } & Utilitarian power & 0.751 & 0.767 \\
& Social regulatory power & 0.797 & 0.807 \\
STAKEHOLDER & Criticality & 0.769 & 0.786 \\
SALIENCE & Time sensitivity & 0.764 & 0.781 \\
& DURABILITY & 0.850 & 0.834 \\
& Importance & 0.719 & 0.728 \\
\end{tabular}

Third, we performed a confirmatory factor analysis for validity. Unlike dimensionality and reliability, there is no general statistical indicator that reflects the validity of the inferences made, and so we revised the necessary evidence: we tested the content validity and construct validity of the scales proposed using the maximum likelihood method and robust estimators. The analysis was performed for each of the model constructs: for both one-dimensional constructs (legitimacy and durability—see Table 5) and multidimensional constructs (power and urgency—see Table 6). The indications showed that the goodness of fit rates for the model are adequate. 
Table 5. Convergent construct validity (first-order CFA).

\begin{tabular}{llll}
\hline FACTOR & VARIABLE & $\lambda$ VALUES & $\chi$ 2/g.1./p/NFI/NNFI/CFI/IFI/MFI/RMSEA \\
\hline & FAVOUR_1 & 0.925 & 7.9039 \\
& FAVOUR_2 & 0.633 & 3 \\
LEGITIMACY & FAVOUR_3 & 0.523 & 0.04804 \\
& FAVOUR_4 & 0.619 & 0.875 \\
& & & 0.829 \\
& FAVOUR_5 & 0.663 & 0.915 \\
& & & 0.919 \\
& & & 0.993 \\
& & 0.068 \\
\hline \multirow{2}{*}{ DURABILITY } & INTERESTS_TIME_1 & 0.523 & 2.6638 \\
& INTERESTS_TIME_2 & 0.751 & 1 \\
& INTERESTS_TIME_3 & 0.814 & 0.10266 \\
& & 0.746 & 0.972 \\
& INTERESTS_TIME_4 & & 0.909 \\
& & 0.786 & 0.982 \\
& & 0.983 \\
& & & 0.998 \\
& & & 0.069 \\
\hline
\end{tabular}

Table 6. Convergent construct validity (second-order CFA).

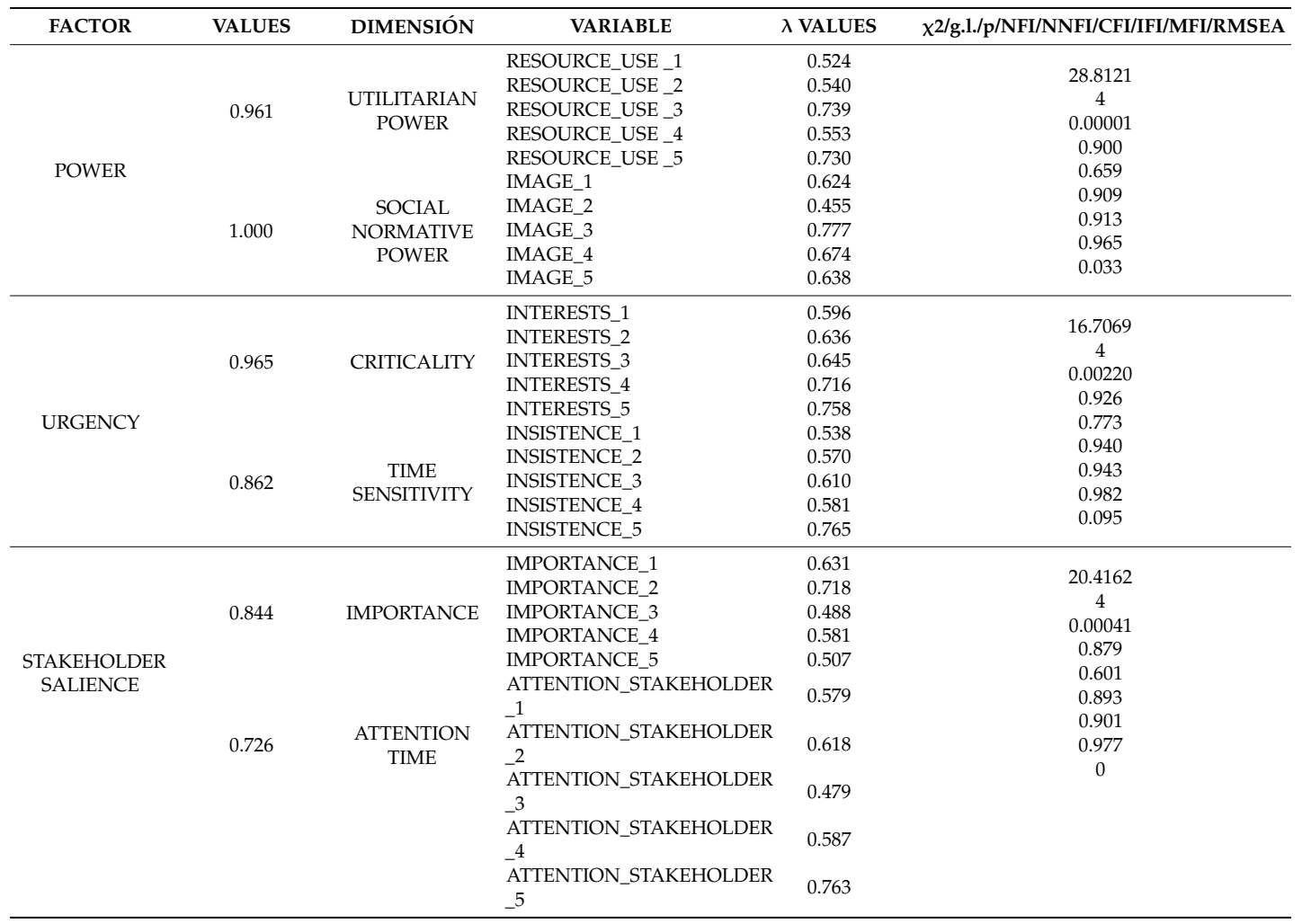

Both the constructs and the dimensions on which the proposed model are based are highly reliable as the results obtained in the analysis are good (or excellent) and indicate content validity and discrimination. These results show that the model is rigorous and meets the standards required by the literature.

\section{Results}

The results obtained in this causal model (Table 7) show that the model has a very good fit with a value $\chi 2$ of 443,6647 and 438 degrees of freedom. Moreover, the other robust indicators are all close to unity, with almost non-existent (0.006) error values (RMSEA). Moreover, the significant relationships 
(marked with $\left.{ }^{*}\right)$ for a confidence level of $95 \%(p>1.96)$ correspond to the assumptions reflected in Figure 1.

Table 7. Rates of goodness of fit of the model.

\begin{tabular}{ccccccccc}
\hline \multicolumn{10}{c}{ Goodness of Fit Indices } \\
\hline$\chi^{2}$ & g.1. & $\mathrm{p}$ & NFI & NNFI & CFI & IFI & MFI & RMSEA \\
443,6647 & 438 & 0.41563 & 0.855 & 0.998 & 0.998 & 0.998 & 0.993 & 0.006 \\
\hline
\end{tabular}

Source: Own calculations.

The first hypothesis regarding legitimacy is confirmed because it largely determines $(0.860)$ the salience of the stakeholders in agri-food cooperatives in Spain and has more influence than power and urgency.

The results determine that the actions of shareholders are considered the most favorable for the organization, closely followed by employees'. This result is comparable with the results obtained by [10]. In this regard, we should not forget that one of the basic pillars of cooperatives is the equal participation of all shareholders in decision-making, so we can see the fulfillment of the interests that led them to join the business.

The actions of employees are considered essential for its proper functioning. This is because (as demonstrated in the empirical work on whether there is an organizational culture among employees in cooperatives and employees in non-cooperatives) employees in cooperative companies are motivated by the values of family security, freedom, and a meaningful and equitable life. These values ensure that activities are satisfactorily performed within the company and these motivations contrast strongly with companies that are not characterized by the cooperative principles and values [30].

Regarding the second hypothesis, we can confirm that in agri-food cooperatives the attribute of power is more influential than urgency in stakeholder salience (0.761).

Therefore, the results obtained differ from the initial model, as well as from the models offered by $[16,31,32]$, where the attribute of power is the most important for explaining the salience of stakeholders.

The first study [16] developed a comparative case study that analyzed the salience of stakeholders on the organizing committee of sports events. The results show that the attribute that best explains the significance of each group is power, followed by urgency and legitimacy. Meanwhile, [31] verified in an empirical study that those companies that have a strategy intended to meet the interests of all stakeholders and that have socially responsible management achieve better economic performance. Thus, to determine the degree of attention given to stakeholders, these authors support the original model and determine that the attribute that best explains the significance of each group is power. In the same vein, [32] categorize various stakeholders while focusing on the power that each group has in relation to the company.

The third hypothesis is confirmed as there are no differences in the level of influence of urgency in the salience of the stakeholders in cooperatives-given that it is the third attribute that determines stakeholder salience (0.624). This is comparable with the results obtained by [10,17]. The results of the structural model confirm that the group that attaches the most importance to its interests and makes the most insistent demands are the shareholders, closely followed by employees. Therefore, the results for criticality match those of timing. As both provide similar results, they do not operate independently (in contrast to the general business case). This is because these companies are comprised of people who associate freely (and who are free to leave the company) to perform business activities that meet their needs and economic and social aspirations at no particular point in time-but with a vision for the present and future. The main interests of the employees are economic, generally meaning higher wages, but they also seek job security and career development.

Finally, durability influences the salience (0.836) of stakeholders; and it can be considered as an attribute in addition to the original stakeholder salience model. 
Shareholders, closely followed by the local community, are the stakeholders with the highest degree of durability in agri-food cooperatives, and their interests are maintained over the long term. Thus, the main demands of shareholders are economic-social: including that the company is managed and performs well; that the products are well marketed; and that there is greater involvement by shareholders. Meanwhile, the main interests of the local community in the agri-food cooperative are that the company creates jobs, generates a good image for the municipality, and produces benefits for the community.

Stakeholders' participants: shareholders (1); employees (2); clients (3); government (4); and the community (5). The significant relationships (marked with *) for a confidence level of $95 \%(p>1.96)$ correspond to the assumptions reflected in Figure 1.

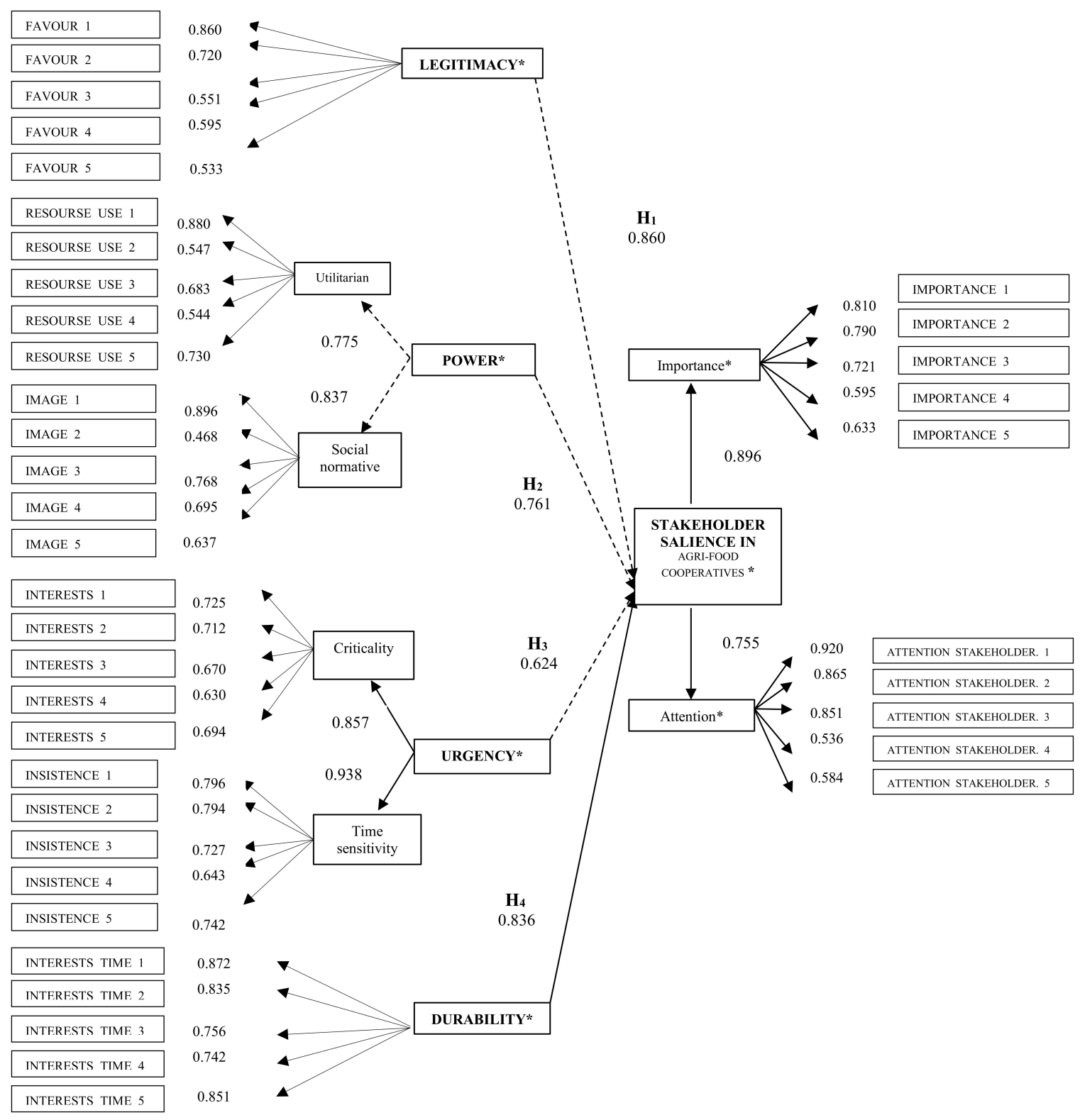

Figure 1. Model results.

\section{Discussion}

The agri-food industry is, in general terms, highly exposed to the challenges and opportunities of sustainability. Direct dependence on natural resources make it a high-impact industry. Demographic, socioeconomic, and climatic trends increase the pressure on the availability and sufficiency of resources [33]. 
On the other hand, cooperatives are companies that have values and principles such as: freedom of participation in production and distribution processes, justice in the distribution of added value generated, and equality in the ability to establish general objectives. Bearing this in mind, it should be noted that business culture, deontological codes, and products with an ethical stamp are factors of competitiveness that are increasingly valued. These companies with democratic characteristics are innovative and influential in terms of participatory management practices. These companies promote widely accepted techniques such as teamwork and collaboration in the value chain. In addition, they can use a suitable structure to increase the competitiveness of a territory, due to the deep roots they have in their territories, as well as their surprising stability; all this is exactly what puts these companies in a strong position in the new global economy [33].

At present, in a technological and institutional transformation, it is necessary that conventional ways of understanding and doing business should be reviewed. This highlights the need to review the theoretical foundations on which our knowledge is based, disconnected from reality. In this situation, the "stakeholder approach" and a growing awareness of business sustainability emerge. A lot of studies appear to analyze how the ownership structure and the institutional framework influence strategic decisions, the allocation of resources, organizational forms, and business results.

The starting hypothesis considers that the government and the management of the agri-food cooperatives are relatively little analyzed in comparison with capital companies. However, through its participatory governance model, the cooperative system is particularly well suited to combine business, social, and environmental objectives. The participatory structure can make it easier to avoid the ethical and legal lapses that have brought down the management of many companies.

However, until now there have been few studies analyzing how cooperatives in the agri-food sector develop their economic, social, and environmental activity through their stakeholders while maintaining their identity. It is necessary, in the first place, to determine to what extent managers must meet the demands of each stakeholder as well as establish the relevance of each group. For this, the original stakeholder salience model [8] has been used and it has been verified that the order of the attributes changes according to the type of company in which this model is studied. In addition, the results confirm the need to add a fourth attribute (durability) to the original model.

\section{Conclusions}

A sustainability-oriented company is fully aware of its responsibilities towards different stakeholders and adopts methods and tools that allow it to improve its social, economic, and ecological performance [7]. However, managerial perceptions of stakeholder salience are likely to be different and more complex in agri-food cooperatives than in institutions that are based on a single dominant logic. Stakeholder cultures differentially influence the perceptions of managers regarding the ascription and subsequent weighting of the three attributes (power, legitimacy, and urgency) to the claims of stakeholder groups. Stakeholder salience is significantly affected by a stakeholder culture and so differs substantially from that advanced in the original model [8].

It is shown that agri-food cooperatives, which ensure that executives are guided by principles and values, have a genuine concern for the interests of stakeholders and that legitimacy is the main attribute determining the perceived importance of each stakeholder group. It is also shown that these companies are sensitive to power issues. Furthermore, the results indicate that the attribute of urgency remains unchanged from the proposed model-independently of the organizational context of the model. However, agri-food cooperatives do differ with respect to the general business case as they do not consider the criticality and urgency as independent aspects.

Our empirical study also enables us to understand how cooperative managers respond to the various problems of stakeholders. Our analysis proposes and includes durability as an attribute for measuring stakeholder salience in agri-food cooperatives. The response to durability in these companies derives from the permanence of the interests of stakeholders in the company-based on a commitment to fulfil social needs. 
We can conclude that the salience perceived by managers may vary depending on the organizational context of the company and its culture. Power and legitimacy can be prioritized differently-which suggests the need to consider the effects of culture and context in businesses.

The study has limitations. It would also be interesting to analyze the effect of stakeholder salience from an evolutionary perspective by using long periods to isolate temporary phenomena and circumstances that may distort the outcome. Moreover, another limitation is that the study focuses on a particular group of cooperatives, agri-food. It would be interesting to test empirically if there are differences in other sectors of activity.

Author Contributions: Conceptualization, C.P.-O., M.J.H.-O. and E.G.-M.; Methodology, C.P.-O. and M.C.V.-M.; Formal analysis, C.P.-O.; Investigation, C.P.-O. and M.J.H.-O.; Writing-original draft preparation, C.P.-O.; Writing-review and editing, C.P.-O.; Supervision, C.P.-O., M.J.H.-O., E.G.-M. and M.C.V.-M.

Funding: This research received no external funding.

Conflicts of Interest: The authors declare no conflict of interest.

\section{Appendix A. Final Questionnaire}

Stakeholders' participants: shareholders (1); employees (2); clients (3); government (4); and the community (5).

\section{PART 1}

Q0. We will start with some questions about the structure and characteristics of the cooperative and its management. Are you a director, manager, or a member of the board of the cooperative? Yes/No/Business or trading name

Q1. How many members does the cooperative have? What is the official classification of the cooperative? First level/ Second level/ Third level

Q3. In which sub-sector does the cooperative trade?

\section{PART 2}

Q1. What is the ability of the following groups to use their resources to influence in the management of the cooperative? (RESOURCE USE _) 1-None / 2-Very Little / 3-Little / 4-Some / 5-Average / 6-High / 7-Very High.

Q2. In your opinion, what influence does each of the following groups have on the public image (reputation) of the cooperative that you manage? (IMAGE $\neg$ ) 1-None / 2-Very Little / 3-Little / 4-Some / 5-Average / 6-High / 7-Very High.

Q3. In your opinion, to what extent do the actions of the following groups favor the activity of the cooperative that you manage? (FAVOR_) 1-Not at All / 2-Very little benefit / 3-A little benefit / 4-Some benefit / 5-Average benefit / 6-Considerable benefit / 7-Great benefit.

Q4. In your opinion, what is the importance that the following groups attribute to their own interests (achievement of their objectives as a group) in relation to the cooperative that you manage? (INTERESTS_) 1-None / 2-Very Little / 3-Little / 4-Some / 5-Average / 6-High / 7-Very High.

Q5. What is the persistence or insistence of the following groups when advancing their interests (achievement of their individual objectives as a group) in the cooperative? (INSISTENCE_) 1-None / 2-Very Little / 3-Little / 4-Some / 5-Average / 6-High / 7-Very High.

Q6. In your opinion, what is the duration of the interests (achievement of their individual objectives as a group) of the following groups in the cooperative? (INTEREST_TIME) 1-Days / 2-Up to 4 weeks / 3-Up to 11 months / 4-One year / 5-Between 1 and 3 years / 6-Between 3 and 5 years / 7-More than 5 years.

Q7. What importance do you attribute to each of the following groups related to the cooperative? (IMPORTANCE_) 1-None / 2-Very Little / 3-Little / 4-Some / 5-Average / 6-High / 7-Very High. 
Q8. Finally, how much time do you dedicate to the interests of each of the following groups? (ATTENTION_STAKEHOLDERS_) 1-None / 2-Very Little / 3-Little / 4-Some / 5-Half My Time / 6-More than half / 7-Much.

\section{PART 3}

Q1. Please indicate your name and gender Male/Female

Q2. Please indicate your age group: 20-30/ 31-40/ 41-50/ 51-60/ OVER 60

Q3. Please indicate your educational level: None/ Primary school/ Secondary school/ High School/ University studies.

\section{References}

1. Bretos, I.; Marcuello, C. Revisiting globalization challenges and opportunities in the development of cooperatives. Ann. Public Coop. Econ. 2017, 88, 47-73. [CrossRef]

2. Wu, X.; Ding, Y. The Service Supply Effect of Cooperatives under Economic Transformation: A Demand-Supply Perspective. Sustainability 2018, 10, 3075. [CrossRef]

3. Confederación de Cooperativas Agroalimentarias de la UE, COPA-COGECA. El Desarrollo de las Cooperativas Agrícolas en la UE. 2015. Available online: http:/ / www.agro-alimentarias.coop/ficheros/ doc/04519.pdf (accessed on 25 October 2018).

4. Observatorio del Cooperativismo Agrario Español, OSCAE. Macromagnitudes del Cooperativismo Agrario Español. 2017. Available online: http:/ / www.agro-alimentarias.coop/ficheros/doc/05708.pdf (accessed on 15 September 2018).

5. Paváo, Y.M.; Rossetto, C.R. Stakeholder Management Capability and Performance in Brazilian Cooperatives. Revista Brasileira de Gestão de Negócios 2015, 17, 870-889.

6. Post, J.E.; Preston, L.E.; Sachs, S. Managing the extended enterprise: The new stakeholder view. Calif. Manag. Rev. 2002, 45, 6-28. [CrossRef]

7. Perrini, F.; Tencati, A. Sustainability and Stakeholder Management: The Need for New Corporate Performance Evaluation and Reporting Systems. Bus. Strateg. Environ. 2006, 15, 296-308. [CrossRef]

8. Mitchell, R.K.; Agle, B.R.; Wood, D.J. Toward a theory of stakeholder identification and salience: Defining the principle of who and what really counts. Acad. Manag. Rev. 1997, 22, 853-886. [CrossRef]

9. Clemens, B.; Gallagher, S. Stakeholders for Environmental Strategies: The Case of the Emerging Industry in Radioactive Scrap Metal Treatment; Andriof, J., Waddock, S., Husted, B., Rahman, S., Eds.; Unfolding Stakeholder Thinking 2, Greenleaf Publishing: Yorkshire, UK, 2003; pp. 128-144.

10. Agle, B.R.; Mitchell, R.K.; Sonnenfeld, J.A. Who matters to CEOs? An investigation of stakeholder attributes and salience, corporate performance, and CEO values. Acad. Manag. J. 1999, 42, 507-525.

11. Pfeffer, J.; Salancik, G. The External Control of Organizations: A Resource Dependence Perspective; Harper \& Row: New York, NY, USA, 1978.

12. Cyert, R.M.; March, J.G. The Behavioral Theory of the Firm; Prentice Hall: Englewood Cliffs, NJ, USA, 1963.

13. Mitchell, R.K.; Agle, B.R.; Chrisman, J.J.; Spence, L.J. Toward a Theory of Stakeholder Salience in Family Firms. Bus. Ethics Q. 2011, 21, 235-255. [CrossRef]

14. Suchman, M. Managing Legitimacy: Strategic and Institutional Approaches. Acad. Manag. Rev. 1995, 20, 571-610. [CrossRef]

15. Donaldson, T.; Dunfee, T.W. Ties That Bind: A Social Contracts Approach to Business Ethics; Harvard Business School Press: Boston, MA, USA, 1999.

16. Parent, M.M.; Deephouse, D.L. A case study of stakeholder identification and prioritization by managers. J. Bus. Ethics 2007, 75, 1-23. [CrossRef]

17. Neville, B.A.; Bell, S.J.; Whitwell, G.J. Stakeholder Salience Revisited: Refining, Redefining, and Refueling an Underdeveloped Conceptual Tool. J. Bus. Ethics 2011, 102, 357-378. [CrossRef]

18. Jones, T.M.; Felps, W.; Bigley, G.A. Ethical Theory and Stakeholder-Related Decision: The Role of Stakeholder Culture. Acad. Manag. Rev. 2007, 32, 137-155. [CrossRef]

19. Etzioni, A. Epigénesis de la unificación política. In Los Cambios Sociales; Siglo XXI: México City, México, 1964; pp. $428-442$. 
20. Martins, H.F.; Rubens, J. ¿En quién se pone el foco? Identificando stakeholders para la formulación de la misión organizacional. Revista del CLAD Reforma y Democracia 1999, 15, 1-18.

21. Jawahar, I.M.; Mclaughlin, G.L. Toward a Descriptive Stakeholder Theory: An Organizational Life Cycle Approach. Acad. Manag. Rev. 2001, 26, 397-414. [CrossRef]

22. Coff, R. When Competitive Advantage Doesn't Lead to Performance: Resource-based Theory and Stakeholder Bargaining Power. Organ. Sci. 1999, 10, 119-133. [CrossRef]

23. Frooman, J. Stakeholders influence strategies. Acad. Manag. Rev. 1999, 24, 191-205. [CrossRef]

24. Savage, G.; Nix, T.; Whitehead, C.; Blair, J. Strategies for assessing and managing organizational stakeholders. Acad. Manag. Exec. 1991, 5, 61-75. [CrossRef]

25. Everett, J.S.; Neu, D.; Martínez, D. Multi-Stakeholder Labour Monitoring Organizations: Egoists, Instrumentalists, or Moralists? J. Bus. Ethics 2008, 81, 117-142. [CrossRef]

26. Núñez-Cacho, P.V. Los Efectos de la Formación y el Desarrollo de los Recursos Humanos en el Rendimiento de las Empresas Familiares Españolas. Ph.D. Dissertation, University of Jaén, Jaén, Spain, 2010.

27. Caballero, G.; García, J.M.; Quintás, M.A. El tiempo y la atención dedicados a los stakeholders: Un análisis empírico aplicado a la empleabilidad del alumnado de la universidad española. Revista Europea de Dirección y Economía de la Empresa AEDEM 2008, 17, 43-60.

28. Anderson, J.C.; Gerbing, D.W. The effect of sampling error on convergence, improper solutions and goodness of fit indices for maximun likelihood confirmatory factor analysis. Psychometrika 1984, 49, 155-173. [CrossRef]

29. Bagozzi, R.P.; Yi, Y. On the evaluation of structural equation models. J. Acad. Mark. Sci. 1988, 16, 79-94. [CrossRef]

30. Diaz, F.; Jaimez, M. ¿Existe una cultura cooperativa organizacional en trabajadores cooperativistas y no cooperativistas? REVESCO Rev. de Estudios Coop. 2009, 97, 44-57.

31. Peloza, J.; Papania, L. The Missing Link between Corporate Social Responsibility and Financial Performance: Stakeholder Salience and Identification. Corp. Reput. Rev. 2008, 11, 169-191. [CrossRef]

32. Podnar, K.; Jancic, Z. Towards a categorization of stakeholder groups: An empirical verification of a three-level model. J. Mark. Commun. 2006, 12, 297-308. [CrossRef]

33. Ministerio de Economía y Empresa de España. 2017. Available online: http://www.mineco.gob.es/portal/ site/mineco/ (accessed on 21 January 2019). 